\title{
G) HitșTó
}

\section{A Insurreição anarquista de 1918}

\author{
The anarchist insurrection of 1918
}

\section{Hamilton Moraes Theodoro dos Santos*}

Resumo: O objetivo do presente artigo é analisar a insurreição anarquista ocorrida em I9I8 no Rio de Janeiro. Um fato singular nas lutas operárias no Brasil. Para analisa-la precisamos aprofundar nosso estudo sobre o sindicalismo revolucionário dentro do movimento operário brasileiro, de inspiração anarquista, durante as duas últimas décadas da Primeira República. O movimento operário organizado através do sindicalismo revolucionário tinha o intuito de alcançar melhorias materiais, condições de trabalho e emancipação do proletariado. Esses objetivos seriam alcançados através de mecanismos de resistência direta ao capitalismo, visando a sua superação e consequentemente a construção de um mundo produtivo realmente justo. A insurreição anarquista de I9I8 estava inserida dentro do contexto de mobilizações proletárias do período. Consideramos o referido fato como um desdobramento do sindicalismo revolucionário no Brasil, influenciado pela Revolução Russa. Assim torna-se necessária a compreensão da influência da Revolução Russa no movimento operário brasileiro do período. A Revolução Russa influenciou e proporcionou novas perspectivas organizacionais e metodológicas para movimentos operários em diversas regiões do planeta e no Brasil não foi diferente.

Palavras-chave: anarquismo; sindicalismo; revolução.

Abstract: The purpose of this article is to analyze the anarchist insurrection that took place in I9I8 in Rio de Janeiro. A singular fact in the worker's struggles in Brazil. In order to analyze it, we need to deepen our study of revolutionary unionism within the anarchist-inspired Brazilian worker's movement during the last two decades of the First Republic. The worker's movement organized through revolutionary unionism was intended to achieve material

\footnotetext{
" Doutorando pelo Programa de Pós-Graduação em História Comparada da Universidade Federal do Rio de Janeiro (PPGHC-UFRJ). O presente trabalho foi realizado com apoio da Coordenação de Aperfeiçoamento de Pessoal de Nível Superior - Brasil (CAPES) - Código de Financiamento ooı.
} 


\section{C) HitcastórRICA}

improvements, working conditions and the emancipation of the proletariat. These objectives would be achieved through mechanisms of direct resistance to capitalism, aiming at overcoming it, and consequently building a truly fair productive world. The anarchist insurrection of 1918 was inserted within the context of proletarian mobilizations of the period. We consider this fact as a result of revolutionary unionism in Brazil, influenced by the Russian Revolution. Thus, it is necessary to understand the influence of the Russian Revolution on the Brazilian labor movement of the period. The Russian Revolution has influencied and provided new organizational and methodological perspective for worker's movements in different regions of the planet, and in Brazil it was no different.

Keywords: anarchism; unionism; revolution.

\section{Introdução}

Nosso objetivo é analisar a insurreição anarquista ocorrida em I9I8 no Rio de Janeiro. Um fato singular nas lutas operárias no Brasil. Pouco divulgado, analisado e propagado. Para sua compreensão precisamos aprofundar nosso estudo sobre o sindicalismo revolucionário, de inspiração anarquista, em nosso país, durante as duas últimas décadas do século XX. A insurreição anarquista de I9I8 está inserida nesse contexto sindical. Acreditamos que uma análise apurada a respeito da insurreição anarquista de I9I8 deve ser realizada relacionandoa com a Greve Geral de 1917 e a Revolução Russa. São fatos que nos permitem um melhor entendimento do nosso objeto de estudo.

\section{Sindicalismo revolucionário}

No início do século $\mathrm{XX}$ os trabalhadores brasileiros se organizaram através do sindicalismo revolucionário, com o anarquismo enquanto principal referência ideológica. Trabalhadores aprimoraram seus mecanismos de organização e luta com o objetivo de alcançar melhores condições de sobrevivência, trabalho e a superação do modo de produção capitalista.

Em abril de 1906 foi realizado o Primeiro Congresso Operário Brasileiro no Rio de Janeiro. Aconteceu no Centro Galego. Foram estabelecidas as bases para criação de uma central sindical inspirada pelo sindicalismo revolucionário, nos moldes da CGT francesa, com o intuito de organizar o movimento sindical brasileiro a nível nacional. Dois anos 


\section{C) Hitcastórica}

depois, em 1908, foi criada a Confederação Operária Brasileira (COB). Foi promulgada a orientação de transformar associações operárias em sindicatos, estes comporiam federações e estas integrariam a COB. Da mesma forma foi aprovada a orientação do proletariado não se organizar através de partidos políticos. A corrente política predominante no congresso foi o sindicalismo revolucionário. Outra importante resolução foi a luta pelas oito horas diárias de trabalho sem diminuição salarial. (SANTOS, 20I8, p. 73-76).

Em 1908 foi criado o jornal $A$ Voz do Trabalhador para promover as orientações e atividades da COB. Logo em seu primeiro número, os leitores foram informados de que a tiragem do jornal seria inicialmente quinzenal, sendo cobrados Ioo réis para aquisição do jornal avulso. Sua redação era na rua do Hospício, $n^{\circ}$ 156, sobrado. A referência ao sindicalismo revolucionário está registrado em seu primeiro número, publicado em I de julho de 1908:

Iniciamos com o presente número a publicação periódica de A Voz do Trabalhador, órgão de uma coletividade formada com a intenção de agremiar e reunir as associações que tenham uma orientação nitidamente revolucionária, e com um programa claro e preciso, elaborado no Congresso Operário, exposto e difundido sempre que apresentou oportunidades e não faltaram meios. O que desejamos, e havemos de conseguir, custe o que custar - é a emancipação dos trabalhadores da tirania e exploração capitalista, transformando o atual regime econômico do salariato e do patronato num regime que permita o desenvolvimento de organizações de produtores-consumidores, cuja célula inicial está no atual sindicato de resistência ao patronato. Como meio prático, como método de luta para alcançar tal desiratum, adotará e usará o sindicalismo revolucionário. (...) É preciso não descansar um instante, o verdadeiro revolucionário só descansa no túmulo. Só pedimos uma cousa: atividade, atividade e sempre atividade." ${ }^{2}$

Entre os dois congressos operários aconteceram mobilizações operárias, diversas greves em diversas fábricas, gerais em algumas cidades, generalizadas em certos Estados. (HARDMAN; LEONARDI, I99I, p.272 e 273). O periódico A Voz do Trabalhador voltou a

${ }^{2}$ A Voz do Trabalhador $n^{\circ}$ I (ol/o7/1908). 


\section{C) Gitcastórica}

circular em $\mathrm{I}^{\circ}$ de janeiro de I9I3, passando a ser uma publicação quinzenal e alcançando a espantosa tiragem de quatro mil exemplares, o que foi considerado um feito para a época. $\mathrm{O}$ número 22 do jornal $A$ Voz do Trabalhador, publicado em $\mathrm{I}^{\circ}$ de janeiro de 1913 , descreve o reaparecimento desse importante periódico na matéria intitulada "Aqui estamos":

Reaparece, hoje, a Voz do Trabalhador. Para que a luta iniciada com este ressurgir seja mais profícua, fecunda e duradoura é mister que todos que vivem esmagados, tolhidos em suas liberdades, pelo patronato odiento, e por toda a quadrilha de verdugos, se dediquem com ardor, com amor verdadeiro, à causa que é de nós todos, auxiliando cada qual na altura de suas posses, o periódico que se propõe, continuando a sua publicação, por um lapso de tempo interrompida, ser o eco vibrante, como já o foi, das nossas aspirações, o veículo da nossa revolta e o semeador criterioso que levará em todos os recantos onde houver um oprimido a seiva do sindicalismo para que ele o compreenda e possa preparar-se, organizar-se e dar combate ao seu opressor fazendo o recuar, titubear o alfim tombar dando margem a uma vida nova e uma sociedade equitativa, sem amos e sem leis! A Voz do Trabalhador agora reaparecendo continua o seu programa traçado por ocasião do $\mathrm{I}^{\circ}$ Congresso Operário de 1906 e ao qual durante o tempo em que pode ser publicada conservou-se sempre fiel. ${ }^{3}$

O Segundo Congresso Operário foi realizado no ano de 1913, também no Rio de Janeiro, desta vez no Centro Cosmopolita, que abrigava o Sindicato de Trabalhadores em Hotéis, Cafés, Restaurantes e Similares, localizado na rua do Senado, 215. Nele foram rechaçadas as agitações de partidos políticos entre os trabalhadores organizados por confundi-los e retirálos do movimento de resistência à opressão burguesa. Da mesma forma, ficou decidido que os operários deveriam fazer propaganda libertária para combater o capitalismo através do teatro, cartazes, conferências, excursões e principalmente jornais. O congresso afirmou que a imprensa operária era fundamental para organizar os trabalhadores brasileiros. Foi aprovada uma moção de ênfase nos sindicatos operários de resistência, pois teriam reais condições de representar os interesses do proletariado, abolir o capitalismo e o Estado. Foram elaboradas estratégias de luta pelo salário mínimo e a conquista das oito horas diárias

${ }^{3}$ A Voz do Trabalhador $n^{\circ} 22$ (OI/oI/1913). 


\section{C) GitistóñóRICA}

de trabalho. Esta ainda não fora alcançada por muitas categorias de trabalhadores. (HALL; PINHEIRO, I979, p. I88-202).

Os anarquistas estiveram na liderança dos dois primeiros congressos operários. Tal fato nos permite afirmar a hegemonia da estratégia do sindicalismo revolucionário dentro do movimento operário na segunda década da Primeira República. (SANTOS, 20I8, p. 89-9I).

\section{Greve geral de 1917}

O ano de 1917 foi emblemático para o movimento operário no Brasil. O fortalecimento da luta dos trabalhadores trouxe grande preocupação para as autoridades e burguesia. Vários fatores explicam a eclosão daquela que foi considerada a maior greve geral da História do país: as inóspitas condições de trabalho, baixos salários, ausência de direitos trabalhistas que regulassem as relações de produção, exaustivas jornadas diárias de trabalho, péssimas condições de vida, principalmente de moradia, entre outros. $\mathrm{O}$ aumento dos preços dos alimentos também deve ser considerado como um dos fatores que contribuíram para a sublevação dos trabalhadores tanto em São Paulo e no Rio de Janeiro.

Em junho aconteceram algumas greves em fábricas têxteis no Mooca e no Ipiranga. No dia 7 de julho, a greve se espalhou para a Cia. Antárctica no Mooca. Dois dias depois a Força Pública reprimiu com violência uma concentração de trabalhadores na porta da Tecelagem Mariângela, que pertencia ao grupo Matarazzo. O sapateiro anarquista Antonio Martinez foi morto durante a repressão e sua morte revoltou os operários paulistas. $\mathrm{O}$ enterro do militante anarquista aconteceu no dia II de julho, tornando-se um catalisador de toda revolta operária contra as condições de trabalho e intensa repressão governamental. $\mathrm{O}$ cortejo fúnebre saiu do Brás, acompanhado de milhares de trabalhadores, foi até o Aterro do Carmo, caminhando pelo centro da cidade, onde aconteceram enfrentamentos com as forças de repressão e chegou ao cemitério do Araçá. A greve se generalizou por toda a cidade. (HARDMAN; LEONARDI, I99I, p. 280).

A greve foi se espalhando por várias cidades do interior paulista e ganhou a solidariedade da Federação Operária do Rio de Janeiro. No dia 15 de julho o número de grevistas era de 50 mil. A cidade de São Paulo ficou completamente paralisada. O movimento operário enfrentou abertamente a classe dominante, organizada através de um forte e violento aparato repressivo governamental. O governo paulista solicitou reforços para o governo federal, temendo o crescimento do movimento grevista e o avanço da greve geral. 


\section{C) Gitiston'RICA}

Foram deslocadas tropas do interior e dois navios de guerra para a cidade de Santos. Os trabalhadores estavam revoltados, deflagrados em uma revolta popular. Lutas de rua, ataques contra autoridades, piquetes e comícios aconteceram por todo o canto. Bairros operários se tornaram baluartes de resistência grevista com formação de barricadas, esconderijos nos cortiços e becos dos bairros da Lapa, Brás, Ipiranga, Belenzinho, Cambuci, Barra Funda e Mooca. Assim registrou Everardo Dias:

São Paulo é uma cidade morta: sua população está alarmada, os rostos denotam apreensão e pânico porque tudo está fechado, sem o menor movimento. Pelas ruas, afora alguns transeuntes apressados, só circulavam veículos militares requisitados pela Cia. Antárctica e demais indústrias, com tropas armadas de fuzis e metralhadoras. Há ordem de atirar sobre quem fique parado na rua. Nos bairros fabris do Brás, Mooca, Barra Funda, Lapa, sucedem-se tiroteios com grupos populares; em certas ruas já começaram a fazer barricadas com pedras, madeiras velhas, carroças viradas e a polícia não se atreve a passar por lá, porque dos telhados e cantos partem tiros certeiros. Os jornais saem cheios de notícias, sem comentários quase, mas o que se sabe é sumamente grave prenunciando dramáticos acontecimentos. (DIAS, I977, p. 56 e 57).

No Rio de Janeiro a União dos Operários em Construção Civil havia sido refundada como União Geral da Construção Civil (UGCC) em abril de 1917. A organização cresceu consideravelmente no ano de 1917. Apenas dois meses após sua refundação já contava com 500 operários filiados. Alcançou grande notoriedade após reunir 20 mil trabalhadores no sepultamento dos 13 operários mortos no desabamento do New York Hotel. O enterro se transformou em uma manifestação de protesto dos trabalhadores da construção civil contra a falta de condições de trabalho e de vida. (RAMOS; SAMIS, 2009, p. 4).

A greve geral se espalhou e chegou ao Rio de Janeiro. No dia I8 de julho o marceneiro Flávio dos Santos abandonou o serviço em um ato de solidariedade ao movimento grevista de São Paulo. De todos os seus I8o companheiros de trabalho, apenas três o acompanharam em sua atitude solidária. No entanto, em uma fábrica de móveis 150 trabalhadores entraram em greve. Em seguida, outras cinco fábricas entraram em greve. A Federação Operária do Rio de Janeiro atuou junto aos trabalhadores grevistas e juntos decidiram que os mesmos só retornariam ao trabalho quando os patrões instituíssem oito horas de trabalho diárias, 


\section{C) GitistóróRICA}

salário de oito mil réis, abolição de trabalho de menores e a responsabilidade patronal sobre os acidentes de trabalho. A Federação Operária do Rio de Janeiro se preparou para deflagrar uma greve geral no dia 22 de julho. (DULLES, 1977, p. 56 e 57).

A União Geral da Construção Civil juntamente com a Federação Operária do Rio de Janeiro e outras associações de resistência declararam a greve geral na capital no referido dia. A repressão foi imediata. A polícia fechou várias sedes de sindicatos, destruindo-as. Contudo, a repressão não conseguiu impedir a eclosão da greve geral. (RAMOS; SAMIS, 2009, p. 4).

No dia 23 de julho 50 mil operários estavam em greve. Cerca de 20 mil metalúrgicos abandonaram o serviço. Alfaiates e entregadores de pão também decidiram aderir ao movimento. Sapateiros criaram, no dia 24, a União dos Cortadores de Calçados para exigir oito horas de trabalhos diários e 20 por cento de aumento salarial. Trabalhadores da companhia de tecidos América Fabril também entraram em greve exigindo 30 por cento de aumento salarial e escola para seus filhos. Os operários da Fábrica de Tecidos Aliança cruzaram os braços e exigiram aumento de 30 por cento e o fim dos castigos corporais.

Os locais de trabalho eram infectos, sem bebedouros ou chuveiros; existia apenas um buraco no chão que servia de privada, deixando que se espalhasse pela oficina um mal cheiro que nos dias de calor provocava náuseas... Certa vez, numa oficina da rua do Rosário, I09, vi um crioulinho que decepara o dedo fugir apavorado em direção à Santa Casa, com medo de ser punido pelo mestre. Não havia trabalho para operários idosos nem para quem usasse óculos. Vivíamos atormentados pela ideia de perdermos o emprego ou ficarmos doentes, apavorados com a proximidade da velhice, imensa fábrica de mendigos. ${ }^{4}$ (RODRIGUES, 1979, p. 206 e 207).

Grupos de trabalhadores tomaram as principais ruas da capital convencendo trabalhadores de diversas categorias a entrarem na greve geral que estava em crescimento. No dia 24 de julho a polícia atacou com violência os grevistas. A multidão de trabalhadores se revoltou contra a violência policial e caminhou para o Largo de São Francisco, tradicional local de concentração de protestos populares. As forças de repressão impediram a entrada

4 Ver depoimento de Álvaro Côrrea. 


\section{C) GitistóróRICA}

de operários e a realização de comícios no Largo. A massa de trabalhadores amotinados se dirigiu para a sede da Federação Operária do Rio de Janeiro, no antigo Largo do Capim, e ali discursaram e analisaram o movimento grevista e sua conjuntura. Ao mesmo tempo, em alguns lugares da cidade, outros grupos realizaram depredações. Na Avenida Marechal Floriano Peixoto aconteceu outro confronto de policiais contra populares.

No dia 25 de julho o chefe de polícia, Aurelino Leal, foi categórico em afirmar que a polícia usaria de maior violência repressiva para acabar com os distúrbios na capital. (DULLES, I977, p. 58). Na prática, a burguesia temia o pior: a deflagração de um processo revolucionário, conforme os princípios do sindicalismo revolucionário. O Estado passou a reprimiu com violência qualquer mobilização operária. Aurelino Leal afirmou que:

as autoridades não podem assistir impassíveis os acontecimentos desta ordem, agravados ontem pelos gritos subversivos e depredações... A polícia proíbe manifestações tendenciosas pelas ruas da cidade, em que já se sente atmosfera de pânico. ${ }^{5}$

Na sede da Federação Operária do Rio de Janeiro foi anunciado que todos os operários da capital, independente de classe, estavam em greve. O chefe de polícia Aurelino Leal informou ao presidente Venceslau Brás que havia solicitado o fechamento da sede da Federação Operária e do Centro Cosmopolita, pois serviam de base para os operários insurgentes e estes haviam recebido a polícia a tiros. A solicitação foi atendida. Aurelino explicou que tal medida atendia a uma necessidade, pois a maioria dos operários era estrangeira, baseada no Centro Cosmopolita. Os operários teriam atingido as autoridades com pedradas e tiros. Afirmou que:

Não convém esquecer que foi na Federação Operária que, em maio desse ano, se pregou o assassinato do chefe de polícia; que foi uma comissão desta mesma entidade que se portou inconvenientemente no palácio presidencial, dizendo que ia mais impor do que pedir ao chefe do Estado uma determinada providência (...). A Federação Operária era e é o centro dos anarquistas do Rio de Janeiro, de organização dúbia, se não escusa, e

${ }_{5}^{5}$ Correio da Manhã (25/07/1917). 


\section{C) HitistóñICA}

onde, na opinião de vários operários honestos, se explora a boa fé dos trabalhadores incautos. ${ }^{6}$

O movimento grevista continuou se fortalecendo no Rio de Janeiro, com a adesão de vários operários e também de trabalhadores da limpeza pública. Percebendo que somente a repressão não acabaria com a revolta operária, vários patrões resolveram negociar com representantes dos operários de diferentes categorias. Parte do proletariado alcançou vitórias parciais referentes aos aumentos salariais, horas diárias de trabalho e que nenhum trabalhador poderia ser desempregado por ter participado do movimento grevista. (DULLES, I977, p. 59).

Foi a maior greve geral da história do país. Os resultados alcançados foram diferenciados de acordo com cada categoria com vitórias parciais alcançadas. A greve geral de 1917 proporcionou o surgimento de novos sindicatos e os antigos alcançaram grande crescimento. Em São Paulo a Federação Operária foi reconstituída, unindo-se a ela dezesseis sindicatos e oito Ligas Operárias. (MARAM, I979, p. I36).

A greve geral coincidiu com o clima de xenofobia que estava se desenvolvendo devido a Primeira Guerra Mundial. Muitos estrangeiros eram alvos em potencial de perseguição e preconceito. As autoridades usaram o clima de guerra para criminalizar parte do movimento operário, pois muitos militantes operários eram anarquistas estrangeiros e foram acusados de serem marionetes de interesses internacionais. Aproveitando o clima patriótico a favor da guerra, o governo de São Paulo se empenhou para punir ativos militantes do movimento operário. Com a declaração do estado de sítio por causa da entrada do Brasil na Primeira Guerra, os governantes utilizaram a situação para agir de forma severa contra o movimento operário. (DULLES, 1977, p. 59-6I).

Já em agosto, as autoridades paulistas se empenharam para esmagar o movimento e seu vertiginoso crescimento. Os governantes do Rio de Janeiro procederam da mesma forma. Sindicatos foram ameaçados de fechamento caso seus militantes anarquistas não fossem expulsos. As sedes dos sindicatos foram invadidas, fechadas a cadeado, as cadeias ficaram cheias de operários atuantes no movimento sindical. No final desse ano, foi aprovado um aumento de $16 \%$ na verba destinada ao exército estadual e foram contratados mil novos

${ }^{6}$ Correio da Manhã (26/07/I9I7). 


\section{C) GitistóróRICA}

soldados. A greve geral levou as autoridades a investir e aprimorar as forças policiais e militares. (MARAM, 1979, p. 137).

\section{Revolução russa de 1917}

No mesmo ano, meses depois, aconteceu a revolução marxista na Rússia. Esse fato fortaleceu o sindicalismo revolucionário no Brasil. A Revolução Russa demonstrou que o proletariado possuía condições e meios de alcança-la findando o capitalismo. Potencializou ainda mais essa esperança, mesmo com incertezas e ausência de informações concretas a respeito de tal evento. A revolução bolchevique acabou se transformando na vanguarda de todo projeto revolucionário marxista. ${ }^{7}$ No entanto essa não era a realidade política do proletariado brasileiro. Muitos sindicatos brasileiros e seus militantes confundiram o legado da Revolução Russa. Para entendermos como o movimento operário interpretou a Revolução Russa precisamos analisar como as informações a respeito da mesma foram apresentadas no Brasil. Acreditamos que influenciaram a eclosão da insurreição anarquista de I9I8.

Edgar Leuenroth se encontrava preso, acusado de ser o ideólogo da maior greve geral do país e os operários brasileiros ainda respiravam os efeitos da greve geral, quando começaram a chegar ao Brasil as primeiras notícias sobre a revolução bolchevique. Foram noticiadas através da agência de notícias internacional Havas, que emitia telegramas através de Londres, Paris e Amsterdã. (DULLES, 1977, p. 63).

Os meios de comunicação criaram uma neblina de confusão e proposital desinformação a respeito da Revolução Bolchevique na sociedade brasileira. O objetivo era desinformar a população sobre a chegada do proletariado ao poder na Rússia. Era necessário acalmar o movimento operário que assombrara a burguesia com a maior greve geral já vista em território nacional. No contexto político da Primeira Guerra Mundial, anterior à Greve Geral, em abril de 1917, o nome de Lênin já aparecia nos noticiários brasileiros com grande teor pejorativo. Foi noticiado como agente da espionagem alemã. Guilherme II teria o infiltrado na Rússia com objetivo de espionagem. O jornal O Combate noticiou:

\footnotetext{
7 Após a Revolução Russa muitos partidos comunistas foram fundados em diversos países do mundo. Os três principais na Europa eram o russo, o alemão e o francês. Na América do Sul o partido comunista argentino era o mais importante. O Partido Comunista do Brasil foi fundado em $1922 \mathrm{com}$ forte herança ideológica anarquista entre a maioria de seus fundadores. Ver SANTOS (2018).
} 


\section{G) hitsTórilcA}

Telegramas de Petrogrado dizem que está apurado que o verdadeiro nome de Lênin é Leão Uliadov ${ }^{8}$ e que ele pode ser considerado como chefe da espionagem alemã na Rússia, tendo gasto nos últimos meses vários milhões de rublos. (...) Lênin comunicava-se continuamente com o governo de Berlim, por intermédio do contrabandista Ganedski, que foi preso, e ainda de outros indivíduos que iam a Estocolmo levar e buscar correspondência. ${ }^{9}$

A desinformação da população era o objetivo. Várias notícias eram vinculadas nos principais jornais e meios de comunicação do Brasil. Até mesmo a morte de Lênin foi anunciada pelos periódicos brasileiros. O periódico A Noite afirmou :

Em certos pontos, porém, trabalhadores dirigidos por agentes alemães quiseram fazer demonstrações contra a guerra, os demais operários protestaram, travando-se conflitos de certa importância que exigiram a intervenção da polícia. Em três pontos da cidade explodiram bombas durante os comícios, sendo presos vários suspeitos, entre os quais alguns conhecidos ácratas. (...) O correspondente de um jornal norueguês, na fronteira da Finlândia, anunciou também que foi assassinado em Petrogrado, ontem de manhã, o socialista Lênin, apontado como agente alemão e que fazia propaganda a favor da paz..$^{10}$

O objetivo da imprensa burguesa não era informar e sim desinformar. Notícias a respeito do processo revolucionário bolchevique misturavam anarquistas, bolcheviques e agentes espiões da Alemanha. A prática da desinformação aconteceu também em periódicos internacionais. O legado revolucionário russo deveria ser esvaziado, caluniado, confundido para não servir de inspiração para o proletariado.

O jornal A Época colocou uma notícia falsa sobre Lênin com a legenda O governo russo prende o traidor Lenin. Nela afirmava que: "Os despachos de ontem recebidos referiam a

\footnotetext{
${ }^{8}$ Lênin era um pseudônimo. Seu nome era Vladimir Ilitch Uliánov. Durante os anos de sua militância na clandestinidade, adotou vários pseudônimos. Porém em 1902 passou a utilizar Lênin. Uma referência ao rio Lena da Sibéria, onde foi exilado.

9 O Combate (25/07/1917).

Io A Noite (02/05/1917).
} 


\section{C) HitsTó}

prisão de Lenin por ordem do governo russo. Lenin, como é sabido, foi denunciado publicamente como agente a soldo da Alemanha"."

O que realmente importava era retratar o líder bolchevique como traidor e agente alemão. (BANDEIRA, 2004, p. I28). Os meios de comunicação utilizaram o contexto bélico da Primeira Guerra Mundial para gerar sentimentos contrários à Alemanha e consequentemente produzir um clima de xenofobia para desacreditar Lênin e seus seguidores. Seriam agentes do imperialismo germânico. Assim, tirava-se o foco da luta do proletariado russo contra a burguesia, interpretando o movimento bolchevique como traição ao povo russo e relacionando-o com a espionagem alemã internacional. Quando os bolcheviques conquistam $\mathrm{o}$ poder as notícias a respeito foram disseminadas propositalmente incompletas, desencontradas e confusas. Os periódicos brasileiros seguiam um mesmo padrão, tinham como únicas fontes as agências de notícias Havas e Americana. (BANDEIRA, 2004, p. I4I e I42). Não existia um correspondente brasileiro na Rússia bolchevique, ou qualquer outra fonte de informação. O primeiro brasileiro a colocar os pés na Rússia após a revolução bolchevique foi Antonio Bernardo Canellas somente em 1922. (SALLES, 2005, p. 89).

Circularam notícias informando sobre o fracasso bolchevique como um fato. $\mathrm{O}$ jornal O Estado de São Paulo informou que "o fracasso do movimento bolchevista (leninista) é questão de dias. (...) os cossacos e os minimalistas estão prestes a dominar Petrogrado". ${ }^{2}$ Já o jornal $A$ Noite afirmou que:

Um despacho de última hora anuncia que o Sr. Kerenski foi deposto. O fato vem ainda agravar mais a situação e levará, sem dúvida, o país à guerra civil. A Rússia desde hoje está dividida em dois vastos campos, que se tornarão, talvez, em campos de sangrentas batalhas. Por mais cansado que esteja o Exército, é de acreditar que ainda se conserve imune ao suborno dos agentes alemães. E, de outra parte, os elementos conservadores que são, incontestavelmente, a esmagadora maioria da nação, também devem reagir contra os teóricos, anarquistas que se acumularam em Petrogrado e se apoderaram agora do governo da Rússia. E diante destes acontecimentos,

II A Época (oI/Io/1917).

${ }^{12} \mathrm{O}$ Estado de São Paulo (I2/II/1917). 


\section{C) HițTon T́RICA}

cuja gravidade é inútil esconder, só nos resta esperar pela reação, na certeza de que ela virá ainda a tempo de salvar a Rússia. ${ }^{13}$

Muitos periódicos insistiam em chamar a Revolução Russa de anarquista. Deturpavam, criminalizavam o legado bolchevique e assim atingiam indiretamente o sindicalismo revolucionário no Brasil. Confundia-se marxismo com anarquismo e assim qualquer revolução tornava-se anarquista e sinônimo de destruição da ordem e de interesses imperialistas estrangeiros. Como os setores mais combativos do movimento operário eram anarquistas, qualquer possibilidade de enfrentamento à ordem burguesa, inclusive a revolução bolchevique, tornava-se sinônimo de anarquismo, de destruição da harmonia social e da liberdade. O jornal O País afirmou que:

... a cidade tomou-se, ontem à tarde, de uma inesperada sensação. A notícia da vitória da anarquia russa sobre a ação enérgica e destemerosa do grande Kerenski abateu o ânimo popular, tão habituado estava á bravura com que o grande ditador dominava os mais sérios e grandes levantes contra a situação que vai recompondo a Rússia moderna sobre os escombros do tsarismo asfixiante, libertando-a a um tempo de embriaguez da liberdade súbita, após o secular cativeiro das consciências na Rússia e o castigo do degredo contra os liberais que ousavam até um simples gesto de revolta. Kerenski deposto e os maximalistas senhores do poder. A primeira preocupação dos triunfadores é propor imediatamente a paz com os impérios centrais. ${ }^{14}$

Um artigo publicado pelo periódico O País, intitulado "O desastre moscovita", continuou com a confusão a respeito do advento bolchevique. Em um trecho afirmou que:

(...) a hidra (a anarquia russa) tinha tantas cabeças que a um só homem era impossível dominá-la. Acabou pelo golpe do Soviete de Soldados e Operários que depôs Kerenski e agora suplicava à Alemanha uma paz humilhante, inspirada na covardia fatal de uma nação que se desagrega aos

${ }^{13}$ A Noite $(08 / 11 / 1917)$

${ }^{14}$ O País (09/II/I9I7). 


\section{C) GitisaróríRICA}

pedaços e que, de fato, há muitos meses não passa de uma simples expressão geográfica da Europa. ${ }^{15}$

O Jornal do Brasil reproduziu uma advertência da agência de notícias internacionais Havas sobre uma possível parcialidade das informações oriundas da Rússia. A elas não deveriam ser dados créditos pois: “As notícias da Rússia são suspeitas porque o telégrafo está em poder dos maximalistas." ${ }^{6}$ A advertência do Jornal do Brasil inverteu propositalmente o processo de fabricação das notícias sobre os acontecimentos na Rússia e afirmou que seriam os bolcheviques que estariam manipulando as informações e não os meios de comunicação oficiais. Assim as informações que informavam a adesão de diversos segmentos sociais russos ao bolchevismo seriam interpretadas como uma manipulação de informações para florear uma revolução popular na Rússia.

O movimento operário brasileiro também se confundiu a respeito da natureza da revolução de novembro de 1917. Os anarquistas vibraram com a revolução, considerando que tivesse um caráter libertário. Finalmente a classe operária teria conquistado o poder na Rússia. Nos primeiros anos posteriores ao advento bolchevique, os principais jornais anarquistas a saudaram entusiasticamente. Em 1919, os jornais anarquistas A Plebe e Spartacus publicaram alguns artigos, empolgados com a Revolução Russa. No jornal A Plebe, em or de março de I919, Astrojildo Pereira escreveu um poema saudando a Revolução como uma conquista dos trabalhadores anarquistas russos: "Traze-me, sol esplêndido, as boas novas do estupendo fragor da revolução, que agita e convulsiona as massas: bendito sejas, sol amigo, sol camarada, ó sol anarquista." ${ }^{17}$ No número seguinte de A Plebe, Oiticica também escreveu um poema derramando elogios à anarquia:

Para a anarquia vai a humanidade, que da anarquia a humanidade vem. Vêde como esse ideal de acordo, invade as classes todas do mundo além. Que importa que a fração dos ricos brade, vendo que a antiga lei não se mantém? Hão de ruir as muralhas da cidade, que não há fortalezas contra o bem. Façam das ações dos subversivos crimes. Persigam, matem, zombem, tudo em vão... A ideia perseguida é mais sublime. Pois nos rudes ataques à

\footnotetext{
${ }^{15}$ O País (09/II/I9I7).

${ }^{16}$ O Jornal do Brasil (Io/II/I9I7).

${ }^{17}$ A Plebe (oi/03/1919).
} 


\section{C) HițTon T́RICA}

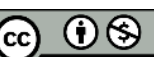

opressão, a cada herói que morra ou desanime dezenas de outros bravos surgirão. ${ }^{18}$

Ambos poemas demonstram uma aceitação inicial dos anarquistas brasileiros à revolução bolchevique. No entanto, a confusão provocada pelos meios de comunicação oficiais pode ter colaborado para a dificuldade dos militantes libertários em interpretar a Revolução Russa.

\section{Insurreição anarquista de 1918}

O ano de I9I8 trouxe grandes expectativas para os operários brasileiros, pois o maior país do mundo era organizado pelo proletariado. Em I9I8 o movimento operário ainda vivia os desdobramentos da greve geral do ano anterior. As autoridades e patrões entendiam que a capital da República era a vitrine do país, qualquer possibilidade de agitação operária poderia se espalhar pelo país. Tal possibilidade preocupava o chefe de polícia Aurelino Leal, que ficava de sobreaviso. Em todo o Brasil o custo de vida estava oneroso para os trabalhadores. O custo de vida aumentava e o poder de compra dos baixos salários dos operários não o acompanhava. De I9I4 a I9I8 o poder aquisitivo dos salários caiu consideravelmente. (ADDOR, 1986, p. 62). A respeito da carestia que atingiu os trabalhadores no ano de 1918, assim escreveu Astrojildo Pereira no segundo número do jornal anarquista Crônica Subversiva: "Não há escassez de produção. Ao contrário, há aumento sensível, segundo se verifica em estatísticas publicadas. Não é, pois, devido a escassez de gêneros que o preço destes tem subido a alturas jamais alcançadas até hoje (...)”.19

Agravando ainda mais essa inóspita situação, a economia brasileira passava por um período de recessão econômica. Em parte a Primeira Guerra Mundial contribuiu indiretamente para a eclosão de uma crise econômica, com a recessão econômica que atingiu o setor dos trabalhadores têxteis. Os trabalhadores dessa indústria faziam parte de uma categoria bem organizada. A recessão trouxe como consequência cortes nos salários dos operários. Outro fator que contribuiu ainda mais para o agravamento das condições de vida da classe trabalhadora foi o surto da famosa "gripe espanhola". Em outubro de I9I8 a cruel e devastadora gripe atingiu parte da população brasileira e ceifou as vidas de I2.22I pessoas. A

\footnotetext{
I8 A Plebe (05/04/1919).

${ }^{19}$ Crônica Subversiva nº 2 (o8/o6/I9I8).
} 


\section{C) GitistóróRICA}

maior parte da população atingida pela gripe foram pessoas pobres, operários que viviam em cortiços, submetidos às insalubres condições de vida, sem a mínima condição de assistência sanitária e condições de higiene adequadas para a sobrevivência em uma grande capital. (ADDOR, 1986, p. 62 e 65).

Logo no dia 20 do primeiro mês do ano, anarquistas da capital federal se reuniram e criaram a Aliança Anarquista do Rio de Janeiro. Tinha por objetivo "congregar esforços na propaganda geral e básica da anarquia, sempre que isso se tornar oportuno e necessário". Em seu processo de criação também ficou decidido que seria realizada uma "publicação mensal de um boletim, ao qual se dará uma feição serena e principalmente documentária”. Assim foi criado o Boletim da Aliança Anarquista do Rio de Janeiro com o objetivo de ser o instrumento de difusão da organização recém criada. Logo em seu primeiro número ficou claro o objetivo da Aliança Anarquista:

Atendendo o apelo de alguns camaradas, os militantes anarquistas residentes nesta cidade, em sua grande maioria, compareceram a uma reunião convocada para o dia 20 de janeiro último, na qual se tratou de dar por terminadas as discussões estéreis travadas em torno do tema 'anarquismo e sindicalismo', constituindo-se, em consequência, a Aliança Anarquista do Rio de Janeiro, organismo de espírito largo e amplo, genérico e fundamental. A Aliança Anarquista não é propriamente uma agrupação no sentido restrito e comum das agrupações libertárias: é antes um órgão de união, de entendimento, de aliança entre todos os anarquistas do Rio de Janeiro formados em grupos ou não. $\mathrm{O}$ seu fim é congregar esforços na propaganda geral e básica da anarquia, sempre que isso se tornar oportuno e necessário. Uma reduzida comissão de relações ficou logo escolhida, resolvendo-se também a publicação mensal deste BOLETIM, ao qual se dará uma feição serena e documentária. ${ }^{20}$

Após as festividades do carnaval, a partir do mês de março o movimento operário passou a se mobilizar efetivamente. O governo federal utilizou o estado de sítio para reprimir o movimento operário. Todas as federações operárias foram fechadas no país. A Federação Operária do Rio de Janeiro já havia sido fechada em agosto de I9I7 pela repressão que atingiu

${ }^{20}$ Boletim da Aliança Anarquista do Rio de Janeiro, ${ }^{\circ}$ I, fevereiro de I9I8. 


\section{C) GitistóróRICA}

o movimento operário após a greve de 1917. Devido a isso, foi criada a União Geral dos Trabalhadores, reunindo sindicatos da capital federal. Reuniu o Centro Operário dos Marmoristas, União Geral da Construção Civil, Sindicato dos Marceneiros, Liga Federativa dos Empregados em Padarias, Sindicato dos Vassoureiros, Sindicato dos Entalhadores. A UGT foi fundada em I9 de março de I9I8 na sede da Federação Operária. Se tornou a nova referência de luta dos operários por melhores dias. (BANDEIRA, 2004, p. I63). Foi uma mudança de nome, de denominação, mas na prática o funcionamento continuava como antes. O Jornal do Brasil assim informou o processo de transição nominal da Federação Operária do Rio de Janeiro para União Geral dos Trabalhadores:

A comissão federal da Federação Operária do Rio de Janeiro discutiu e aprovou todos os atos da comissão pró-unificação, dando por terminada a missão desse organismo (FORJ), por compreender que a nova União está de acordo com as aspirações dos trabalhadores conscientes. ${ }^{21}$

A mobilização e estratégia de luta continuavam anarquistas. A ação direta continuava a ser o principal método de atuação dessas organizações. Nela estavam incluídas diversas formas de luta como passeatas, comícios, greves, sabotagem, boicote e em algumas situações a utilização de bombas. O objetivo era a greve geral para a deflagração de um processo revolucionário. A mobilização dos trabalhadores e a radicalização do movimento operário preocupavam constantemente autoridades e patrões, pois poderiam chegar ao ponto de perder suas vidas através de atentados a bombas. (BANDEIRA, 2004, p. I62 e I63).

Em abril aconteceu uma greve dos sapateiros na luta pelas 8 horas de trabalho diárias. Depois de 15 dias de greve os referidos trabalhadores conquistaram um novo regulamento estabelecendo 8 horas e meia de trabalho por dia. O Centro Cosmopolita aprovou integralmente as bases da União Geral dos Trabalhadores. Outras associações de trabalhadores também aderiram, com destaque para a União dos Alfaiates. Passaram a se organizar para as atividades referentes ao $\mathrm{I}^{\circ}$ de maio. A União dos Operários em Fábricas de Tecidos aumentou ainda mais seu trabalho de organização dos trabalhadores do setor. Começam a surgir rumores na imprensa e entre os operários a respeito de uma nova greve geral, sob o assombro da conquista de poder bolchevique. Tais boatos assustaram as autoridades que pressionaram o chefe de polícia Aurelino Leal para agir. Foi convocada uma

${ }^{21}$ Jornal do Brasil (19/03/19I8). 


\section{C) GitistóróRICA}

reunião na sede da polícia com uma comissão do Centro Cosmopolita. Porém o chefe de polícia não conseguiu persuadi-los a acalmar os trabalhadores. O secretário do Centro, Raymundo Martins, afirmou de forma desafiadora, que seriam os trabalhadores que decidiriam pela possibilidade da greve geral. Três dias depois estava preso. (MARAM, I979, p. 137).

Aurelino Leal abriu um inquérito sobre a União Geral dos Trabalhadores. Tinha por objetivo saber os objetivos e a ideologia que predominavam na organização. Era necessário investigar a ligação da FORJ com a UGT, se havia estrangeiros integrando a nova organização operária e qual o tempo destes no Brasil. As autoridades entendiam a repressão como única resposta à mobilização operária. (ADDOR, I986, p. I35 e I36).

No Rio de Janeiro as comemorações do $\mathrm{I}^{\circ}$ de maio foram distintas das comemorações dos demais anos, pois não aconteceram somente os tradicionais protestos de trabalhadores e manifestações de solidariedade ao primeiro governo proletário russo. O governo brasileiro utilizou o Estado de Sítio para proibir o acesso de cidadãos às ruas. A determinação governamental, através do chefe de polícia, era de que a data fosse comemorada apenas entre quatro paredes. O objetivo era impedir a publicidade de manifestações públicas de trabalhadores no dia $\mathrm{I}^{\circ}$ de maio. Ainda mais após os trabalhadores conquistarem o poder na Rússia e colocarem uma pá de cal sobre o capitalismo naquele país. Porém várias organizações proletárias não respeitaram a determinação governamental e saíram às ruas para se manifestar na importante data.

A União Geral dos Trabalhadores do Rio de Janeiro convocou os trabalhadores para se reunirem e se manifestarem nesse $\mathrm{I}^{\circ}$ de maio. Os operários atenderam a convocação, desafiaram a tal proibição e se reuniram no teatro Maison Moderne ${ }^{22}$, localizado na Praça Tiradentes. Realizaram uma assembleia onde protestaram contra a exploração capitalista, declararam total solidariedade de classe aos trabalhadores ao redor do mundo, condenaram o genocídio causado pela ganância imperialista da Primeira Guerra Mundial, fizeram votos de uma paz firmada entre os trabalhadores do mundo e manifestaram simpatia pelo povo russo em luta contra o Estado e o capitalismo. A fala de abertura foi feita por Carlos Dias, que apontou para a necessidade da revolução social. Foram feitos discursos de apoio a

${ }^{22} \mathrm{O}$ teatro Maison Moderne estava localizado na rua Espírito Santo, esquina com a Praça Tiradentes. Propriedade da família de origem italiana Segretto. Pertencia a Paschoal Segretto, irmão de Gaetano Segretto. A família Segretto introduziu o cinema no Brasil e se dedicou ao ramo das diversões na capital da República no início do século passado. A rua Espírito Santo passou a se chamar Luís Gama e depois Pedro I. Atualmente a área do teatro é ocupada por um prédio de apartamentos chamado Gaetano Segretto. 


\section{C) HitcastórRICA}

Férrer, assassinado pelo governo espanhol alguns anos antes. Os mártires de Chicago foram lembrados. Também houve a declaração de que todos os presentes eram brasileiros, uma resposta direta à imprensa brasileira que fazia circular a ideia do movimento operário brasileiro como uma criação de trabalhadores estrangeiros anarquistas e desajustados. Aos poucos a massa de operários ficou inflamada. O acadêmico anarquista Álvaro Palmeira pediu a palavra e afirmou de onde estava que "a ideia perseguida é a que vence”. José Elias, um dos futuros fundadores do PCB, também agitou as massas presentes quando se declarou anarquista e brasileiro de nascimento. Durante sua fala, agentes policiais presentes tentaram tumultuar a assembleia. O comandante da Policia Militar, major Bandeira de Melo, foi vaiado pela multidão presente. (BANDEIRA, 2004, p. I57 e I58).

Foram aprovadas moções de protestos contra a violência que ceifou a vida dos mártires de Chicago, de repúdio contra a guerra, apoio aos revolucionários russos e solidariedade operária. A reunião acabou por volta das I6 horas de forma pacífica. (ADDOR, I986, p. I43). No dia seguinte às manifestações do $\mathrm{I}^{\circ}$ de maio daquele ano, o jornal $A$ Razão publicou uma mensagem do Centro Panifício, que representava os trabalhadores das padarias:

É hoje o dia do sufrágio universal de todo proletariado como protesto à brutalidade do capitalismo. A magia que toda a matilha (de patrões) sonhava está sendo banida; a aurora reivindicadora que se estende em toda a Rússia não tardará esse facho luminoso a chegar ao continente americano. O prosseguimento desta guerra é o fim dos castelos do capitalismo. Todas as nacionalidades têm de passar pela mesma fase da Rússia, que é o caminho nobilíssimo da grande caminhada. ${ }^{23}$

Mesmo com o decorrer do conflito mundial era marcante a independência de classe do proletariado brasileiro em relação a posição oficial do Itamaraty. O movimento operário não respondeu positivamente aos apelos nacionalistas implementados pelo governo através dos meios de comunicação da época. A consciência e interesses de classe eram o que realmente importava para os trabalhadores. A postura pacífica do movimento operário foi

${ }^{23}$ A Razão (02/05/1918). 


\section{C) Gitisarór RICA}

acusada de traição à pátria, como ficou registrada na nota que o Centro Industrial Gráfico emitiu a respeito: "traidores da pátria". (BANDEIRA, 2004, p. 158).

As manifestações do Primeiro de Maio aconteceram em diferentes regiões do Estado do Rio de Janeiro. Os operários de pedreiras saíram às ruas com bandeiras vermelhas da Praça Tiradentes até a Central cantando o hino da Internacional24, saudando os trabalhadores russos e gritando palavras de ordem de luta dos operários contra a exploração capitalista. Carregavam faixas pela jornada de trabalho de 8 horas de trabalho diário. Realizaram um comício em Madureira. Em Niterói, no Largo das Neves, houve tumulto entre trabalhadores e a polícia. Um soldado chamado Inocêncio Luís Rodrigues se solidarizou com os operários e feriu o comissário de polícia. A mobilização proletária alcançava até mesmo soldados. A Liga dos Sapateiros, a dos Cocheiros, a Resistência do Café, tecelões, carpinteiros navais, marceneiros, remadores e estivadores também realizaram manifestações públicas no dia $\mathrm{I}^{\circ}$ de maio.

Alguns deputados também participaram das comemorações do $\mathrm{I}^{\circ}$ de maio. Afirmaram que direitos trabalhistas eram necessários para a regulação das relações de produção no país e que a Revolução Russa era uma vitória do povo russo. O deputado federal Metello Júnior compareceu na manifestação do $\mathrm{I}^{\circ}$ de maio convocada pela Liga dos Sapateiros e proferiu um discurso a favor dos trabalhadores, apontando a conquista de poder bolchevique como uma consequência da fome e da miséria. Afirmou que o Congresso Nacional aprovaria o Código do Trabalho, e assim as relações de trabalho seriam legalizadas, impedindo a intensa exploração do patronato. Segundo ele, somente dessa forma os interesses patronais e a repressão policial deixariam de ser as únicas regras nas relações de produção. Foi um projeto de lei criado pelo deputado Maurício de Lacerda, uma espécie de embrião da CLT, porém nunca foi votado. O deputado Maurício de Lacerda esteve presente na sede Beneficente $I^{\circ}$ de Maio, em que fez um discurso elogiando a Revolução Russa, pois foi “a revolução que elevou os pequenos e deu à maioria operária o seu verdadeiro lugar na organização social das nações livres”. (BANDEIRA, 2004, p. I60 e I6I).

A principal bandeira de luta do movimento operário brasileiro no ano de 1918 continuava a ser a jornada de 8 horas de trabalho diário. Porém décadas de luta proletária já estavam surtindo resultado para algumas categorias de trabalhadores. A influência da

\footnotetext{
${ }^{24}$ Hino conhecido com A Internacional foi criado em I87I pelo francês Eugene Pottier, que havia participado da Comuna de Paris. Socialistas, anarquistas e comunistas o utilizam. A União Soviética o adotou como hino nacional até a década de 1940.
} 


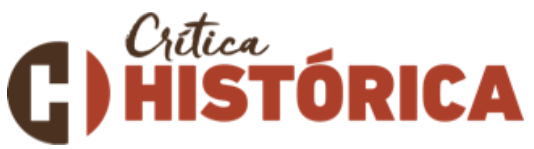

revolução bolchevique era preocupante, pois os trabalhadores russos apoiaram os bolcheviques trabalhando apenas 42 horas semanais, imagina o que poderiam fazer os trabalhadores brasileiros, revoltados, trabalhando o dobro dessa carga horária? O prefeito do Rio de Janeiro, Paulo de Frontin, concedeu as 8 horas para os trabalhadores municipais. O presidente da República Venceslau Brás decidiu por 8 horas e meia de trabalhos diários para os trabalhadores de calçados. Os marítimos do Lóide também conquistaram a almejada carga horária, após constantes lutas contra seus patrões. Outros empregadores decidiram aceitar a insistente reivindicação dos operários por tal carga horária. (BANDEIRA, 2004, p. I6I).

A União Geral da Construção Civil e o Centro Cosmopolita, os dois mais importantes sindicatos representantes do sindicalismo revolucionário, tentaram influenciar a elaboração e aprovação do Código de Trabalho proposto por Maurício de Lacerda. Essas organizações operárias pressionaram a votação desse projeto de leis que regulariam as relações de produção, com o objetivo de que contemplassem algumas importantes reivindicações do movimento operário. (MARAM, 1979, p. 83). O referido projeto de lei também foi tema de um artigo de Astrojildo Pereira no jornalzinho que publicava sozinho, Crônica Subversiva:

É o grande assunto do momento. No parlamento e na imprensa, nas rodas grandes e nas pequenas, toda a gente burguesa reconhece e proclama a urgentíssima necessidade de se regulamentarem as condições de trabalho operário... É interessante notar que só agora tenha a burguesia do Brasil reconhecido essa necessidade. Há duas dezenas de anos que os anarquistas e alguns socialistas, incansavelmente, tem malhado e remalhado essa questão $(. . .)^{25}$

Todavia, essas foram conquistas pontuais de algumas categorias de trabalhadores. A grande maioria dos empregadores permanecia insensível às inóspitas condições de vida e de trabalho da classe trabalhadora. Em meados de I9I8 estavam em greve, lutando pelas 8 horas de trabalho diárias, os gráficos da ilha do Viana, da firma Lage \& Irmãos. Foi convocado um boicote desses produtos pelo sindicato. Prática comum no período. A mobilização operária estava crescendo. Na Cervejaria Brahma acontecia uma greve parcial. Os sapateiros estavam

${ }^{25}$ Crônica Subversiva n ${ }^{\circ}$ I (oI/o6/I9I8). 


\section{C) HitcastórRICA}

em confronto com os diretores das fábricas Cleveland e Colombo. Os trabalhadores da Light também entraram em choque com o patronato na luta por melhores salários e a tão almejada diminuição da jornada de trabalho.

Diante desse quadro de crise econômica e de recessão que assolava o país, o governo decidiu criar, em I2 de junho, o Comissariado de Alimentação Pública através do decreto 13.069. Mesmo assim os anarquistas continuam seu trabalho de mobilização operária. $\mathrm{O}$ Grupo Anarquista Germinal promoveu um festival de teatro, no qual foram apresentadas as peças Ferro em Brasa, Ninete e Náufrago. Também foi realizado um baile familiar e uma conferência sobre a revolução bolchevique, proferida por Álvaro Palmeira, intitulada $a$ revolução maximalista e sua repercussão no mundo. Também foi inaugurada uma sede da UGT no bairro carioca da Piedade. Foi criado o Sindicato Profissional da Indústria Têxtil. Também a União Geral dos Metalúrgicos ampliou seu trabalho de organização operária abrindo frentes na Piedade e em Niterói. (ADDOR, I986, p. I44).

Na mesma toada, a União Geral da Construção Civil criou uma sucursal suburbana. Em 26 de junho de I9I8 a União Geral da Construção Civil, na qual militava Domingos Passos, mudou seu nome para União dos Operários da Construção Civil (UOCC). (RAMOS; SAMIS, 2009, p. 5).

Nos últimos dias de junho os marceneiros entraram em greve reivindicando as almejadas 8 horas de trabalho. Em julho chegam a um acordo com os patrões. Em julho dois mil tecelões da fábrica de tecidos Confiança Industrial entraram em greve. Suas principais exigências eram a redução da jornada de trabalho, aumento salarial, readmissão de 32 trabalhadores demitidos e suspensão dos serões. No dia 8 de julho a greve ganhou maiores proporções, com outras fábricas aderindo ao movimento grevista. Trabalhadores de outras categorias também entraram em greve: operários marmoristas, carvoeiros, estivadores e chapeleiros da fábrica Botafogo. No dia I2 a União dos Operários em Fábricas de Tecidos e os industriais entraram em acordo para acabar com a greve. Ficou decidido que os serões seriam suspensos e os operários demitidos seriam readmitidos. (ADDOR, 1986, p. I44 e I45). Assim registrou Astrojildo Pereira no periódico Crônica Subversiva:

Um movimento belo, pela rapidez e pela segurança, esse dos operários da fábrica de tecidos Confiança Industrial. Greve de solidariedade, a sair vitória absoluta, é uma vitória inconteste da força da solidariedade. Motivou a greve a despedida arbitrária e injusta de 32 operários. O restante do 


\title{
C) HițTon T́RICA
}

pessoal, solidário com os companheiros despedidos, paralisou o trabalho e exigiu a imediata readmissão de todos eles. (....) ${ }^{26}$

Em meados de julho circularam novos boatos de uma greve geral. Ela seria puxada pelos trabalhadores tecelões com adesão de todas as associações operárias filiadas à UGT. No dia 22 terminou a greve dos chapeleiros da fábrica Botafogo, na qual foi conquistado aumento salarial. No dia 29 terminou a greve dos estivadores e também foi alcançado maior salário para a categoria. Assim escreveu Astrojildo Pereira no jornal Crônica Subversiva:

\begin{abstract}
Greve dos tecelões. Greve de leiteiros. Greve de trapicheiros. Greve de carvoeiros. Greve nas oficinas Trajano de Medeiros. Greves, greves, greves... contínuas, diárias, crescentes, em todas as classes operárias, em todos os ramos de trabalho... É o sintoma decisivo para a caracterização do mal estar presente. Estas greves de agora são movimentos absolutamente espontâneos, surgidos irresistivelmente aqui e ali, num ponto e noutro: prova material da generalização da angústia e do descontentamento que minam as classes operárias. (...). ${ }^{27}$
\end{abstract}

Em agosto de I9I8 aconteceu a famosa greve da Cantareira. A Companhia Cantareira e Viação Fluminense, de propriedade de ingleses, tinha o monopólio dos transportes de bondes e das barcas que cruzavam a Baía de Guanabara ligando o Distrito Federal a Niterói. Em julho os empregados que operavam os bondes receberam um aumento de $15 \%$ para os casados e I0\% para os solteiros. Os empregados marítimos da companhia haviam recebido um aumento salarial em fevereiro de 19I8. Acreditaram que receberiam o novo aumento de julho. O custo de vida só crescia e as condições de vida dos trabalhadores só pioravam. Ao receberem seus salários sem o novo aumento, os trabalhadores marítimos se revoltaram por não terem sido contemplados e resolveram entrar em greve no início de agosto. A greve dos trabalhadores das barcas e trabalhadores urbanos de Niterói foi sufocada da mesma forma, com intensa violência pela Força Pública. A Brigada Policial do Distrito Federal e a Capitania dos Portos passaram a operar as barcas e assim aliviar a pressão da greve dos marítimos. Não obstante, trabalhadores de diversas categorias também resolveram entrar em greve exigindo

\footnotetext{
${ }^{26}$ Crônica Subversiva n ${ }^{\circ} 07$ (13/07/1918).

${ }^{27}$ Crônica Subversiva n ${ }^{\circ}$ Io (03/08/1918).
} 


\section{C) HitcastórRICA}

aumento salarial e por solidariedade aos motorneiros e condutores dos bondes da Cantareira em Niterói. Aconteceram violentos confrontos entre a polícia e os trabalhadores grevistas. Várias lojas fecharam suas portas mais cedo por causa da pressão dos populares em apoio aos grevistas. Na noite de 6 de agosto foi necessária a cavalaria para dispersar a multidão com violência. Os trabalhadores insurgentes ganharam ainda mais força quando vários soldados do $58^{\circ}$ Batalhão dos Caçadores do Exército passaram para o lado da população revoltada. O carro que trazia o comandante da polícia militar foi recebido por uma chuva de pedras. As autoridades correram para acusar os anarquistas de terem assediado os soldados do $58^{\circ}$ Batalhão dos Caçadores do Exército. Na noite do dia seguinte uma enorme multidão de trabalhadores grevistas, populares revoltados e militares insurgentes do $58^{\circ}$ Batalhão, se concentrou na Rua da Conceição e lançou gritos anarquistas de morte à polícia, aos governos constituídos, de viva o anarquismo e o internacionalismo.

A cavalaria policial tratou de reprimi-los com violência e o confronto terminou em tiroteio a ponto de a munição da cavalaria se esgotar. Assim a cavalaria teve de ser substituída pela infantaria da polícia estadual. Doze policiais e um número desconhecido de trabalhadores e militares rebelados do exército saíram feridos. Houve duas mortes entre os sublevados: Nestor Pereira da Silva, soldado do $58^{\circ}$ Batalhão e o civil José Oliveira do Amaral. Um ex-condutor de bondes da Cantareira entregou à polícia uma carta endereçada a Astrojildo Pereira, com o número do telefone do Centro Cosmopolita. Assim dizia a carta: "Nem podes imaginar como vão as coisas. A polícia atacou indiscriminadamente soldados do $58^{\circ}$ e populares. Amanhã eles farão somente o policiamento". Astrojildo Pereira e vários anarquistas foram presos. A polícia militar ganhou reforço do Terceiro Regimento de Infantaria do Exército para reforçar as ruas de Niterói. No dia 8 de agosto a paz voltou para as ruas de Niterói, mas o comércio continuou fechado e luzes foram acesas em frente às fachadas dos prédios em homenagem aos mortos. Durante o cortejo fúnebre de Nestor Pereira os operários foram proibidos de discursar. Durante o enterro chegou a notícia de que outro militar do 58 havia falecido: o cabo Antônio Lara França. No dia 9 de agosto o comércio reabriu suas portas sob proteção das forças policiais. Os operários tentaram negociar o fim da greve, pedindo um aumento de 8 a io por cento e a empresa recusou o pedido. Mesmo assim os trabalhadores encerram a greve e voltaram ao trabalho. Novamente os anarquistas foram acusados de estarem por trás do movimento grevista. Pessoas foram presas, entre elas vários militantes libertários, como João da Costa Pimenta, que havia sido padeiro em Campos, mudando-se depois para a capital federal, onde militou no Centro Cosmopolita. Era operário gráfico. (DULLES, 1977, p. 64-66). 


\section{C) Gițistórica}

A condição de vida da classe operária piorava cada vez mais. Em setembro o custo de vida continuava aumentando. Os preços dos gêneros alimentícios cresciam atingindo diretamente as famílias operárias. Os boatos a respeito da greve continuaram circulando. Patrões e governo se mobilizaram para impedir que uma nova greve geral não acontecesse. Alguns operários foram presos preventivamente a mando de Aurelino Leal. A grande imprensa publicou matérias em seus jornais com o intuito de acalmar o proletariado e criminalizar a militância sindical revolucionária. (ADDOR, I986, p. I53). Assim publicou o Jornal do Brasil:

(...) nesse grave momento que atravessa o mundo (...) são inconvenientíssimos quaisquer atritos entre patrões e operários(...). O fermento anarquista, que é sombra do operário laborioso e honesto, atua com um só objetivo: perturbar a ordem jurídica, a paz pública, separando cada vez mais os dois elementos que se devem aproximar numa íntima colaboração - o capital e o trabalho. Contra esse elemento subversivo agirá o Governo com energia na defesa da ordem..$^{28}$

Por outro lado, o trabalho de organização do proletariado através de sindicatos continuou crescendo. Foi fundada a União dos Empregados em Tinturaria. Um artigo de Astrojildo Pereira, publicado na Crônica Subversiva, no final de setembro, registrou o aumento da organização do movimento operário:

Não só o Rio verifica atualmente este promissor reerguimento das energias proletárias. Pelos estados fora, principalmente, como é natural, nas cidades mais industriosas, vai a classe operária reforçando-se nas organizações de classe, sistemáticas e solidárias. Movimentos e agitações se manifestam, aqui e ali, demonstrando vitalidade e consciência. (...) Enfim: há que rejubilar-se ante a aura renovadora, a aura vivificante, a aura fecunda que perpassa, de norte a sul, pela massa proletária do Brasil... A grande hora se aproxima amigos! ${ }^{29}$

\footnotetext{
${ }^{28}$ Jornal do Brasil (2I/08/19I8).

${ }^{29}$ Crônica Subversiva n ${ }^{\circ}$ I3 (2I/o9/1918).
} 


\section{C) GitisátóRICA}

Em outubro a "gripe espanhola" se espalhou pelo país. A epidemia atingiu principalmente os trabalhadores e segmentos mais pobres da sociedade. No dia 15 o Jornal do Brasil publicou uma matéria sobre o Distrito Federal com o seguinte título: "Pânico na cidade - indolência, imprevidência ou incompetência da Saúde Pública?"3o

O alastramento da epidemia dificultou o trabalho de mobilização operária. No fim de outubro diversas organizações operárias criaram o Comitê Pró-Combate à Epidemia com objetivo de organizar os trabalhadores para combater a peste. Com a chegada da epidemia a vida dos trabalhadores ficou ainda mais dura. (ADDOR, I986, p. I58).

A epidemia atingiu todo o país. No Rio Grande do Sul, em Porto Alegre, surgiu a União Maximalista. Foi um dos primeiros grupos operários que buscou se aproximar da ideologia marxista no Brasil. A União Maximalista denunciou que as autoridades não se empenhavam em combater os efeitos da epidemia que acometia principalmente as pessoas pobres. Afirmou que o governo se empenhou para socorrer os ricos somente. Em Pernambuco a "gripe espanhola" acabou com a vida de duas mil pessoas em apenas uma semana, principalmente operários. (BANDEIRA, 2004, p. I67).

Ao fim de I9I8 a situação do proletariado brasileiro não poderia ser pior. Há décadas os operários eram intensamente explorados. A crise econômica, o aumento do custo de vida assediava os brasileiros. Consequentemente, os preços dos alimentos subiram e no fim do ano a gripe ampliou ainda mais a inóspita situação do proletariado. Nesse sofrido contexto a ideia de greve geral fazia sentido, já que as pessoas estavam submetidas a essa situação de penúria, miséria, exploração e desespero. Patrões diminuíram a produção devido à super estocagem das fábricas de algodão e, por conseguinte, os trabalhadores tiveram seus salários ainda mais reduzidos. Greves eclodiram em fábricas de tecidos. No dia 30 a União dos Operários em Fábricas de Tecidos encaminhou um ofício ao Centro Industrial solicitando o abono de 50\% nos salários dos operários parados por causa da epidemia. Patrões e autoridades demonstraram grande despreparo e miopia em sua análise das condições materiais do proletariado, utilizando a polícia para reprimir e prender os trabalhadores que militavam no Comitê Pró-Combate à Epidemia. Não sabiam se relacionar de outra maneira com o movimento operário. Qualquer tipo de organização proletária deveria ser reprimida, mesmo que fosse criada para diminuir os efeitos da gripe espanhola. Com o uso da repressão contra o Comitê Pró-Combate à Epidemia, as autoridades conseguiram piorar ainda mais esse contexto medonho. (ADDOR, I986, p. I58).

${ }^{30}$ Jornal do Brasil (15/Io/1918). 


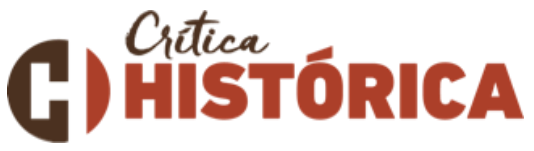

Dentro desse quadro de crise econômica e social, o Centro Industrial do Brasil promoveu uma reunião com os representantes das fábricas de tecidos. Enfatizaram que a conjuntura recessiva, a crise do mercado fabril e o prejuízo financeiro ocasionado pela super estocagem das fábricas não lhes permitiam atender às reivindicações dos operários fabris encaminhadas pela UOFT. (ADDOR, I986, p. I6I). Indignada com a ineficácia das negociações a União dos Operários em Fábricas de Tecidos declarou greve geral. Contudo, a greve não surtiu o efeito necessário, pois as fábricas estavam super estocadas e a recessão econômica criou a possibilidade de fechamento temporário das fábricas, reduzindo sua folha de pagamento em um momento tão delicado. A greve geral veio ao encontro dos interesses patronais. (MARAM, I979, p. 138).

No dia 9 de novembro o Kaiser deixou de governar o país germânico. Alguns dias depois circularam notícias na grande mídia sobre a queda do Kaiser e a revolução na Alemanha. O Jornal do Brasil noticiou: "a Revolução Proletária vitoriosa na Alemanha”. ${ }^{\mathrm{I}} \mathrm{Com}$ grande destaque também foi noticiado o fim da Primeira Guerra Mundial. A população do Rio de Janeiro foi para as ruas comemorar o fim do conflito mundial. Também era grande a expectativa em torno da posse do novo presidente da República, Rodrigues Alves. No entanto, o presidente eleito estava enfermo e não pôde tomar posse no dia 15 de novembro. Somente o vice presidente Delfim Moreira pôde ser empossado.

No final de 1918 os anarquistas do Rio de Janeiro avaliaram o contexto político econômico e social como propício para a eclosão de uma greve geral que poderia culminar em um processo revolucionário. O mundo respirava a revolução russa. E o legado bolchevique mostrava o caminho para a derrubada do capitalismo. No Brasil o movimento operário sindicalista revolucionário acreditou que havia chegado a hora, era possível o trabalhador se organizar para finalmente acabar com o capitalismo e criar uma sociedade libertária. Nesse momento, os operários brasileiros acreditavam que a revolução bolchevique era libertária e se os russos a fizeram, os brasileiros também fariam.

Os militantes anarquistas preparavam a eclosão de um movimento revolucionário para a tomada de poder no coração da República assim como os russos haviam feito em São Petersburgo. Segundo Everardo Dias, ele seria iniciado no Rio de Janeiro para depois se espalhar por São Paulo e pelos estados onde houvesse movimento operário. Anarquistas, socialistas, líderes sindicais e até mesmo grupos democratas insatisfeitos com a situação do

${ }^{31}$ Jornal do Brasil (II/II/1918). 


\section{C) Hitistór RICA}

país se envolveram no planejamento do movimento revolucionário. Não obstante, $\mathrm{o} 2^{\circ}$ tenente do Exército, Jorge Elias Ajus, infiltrou-se no movimento conspiratório e passou a informar diariamente à polícia os passos dos operários insurgentes. O jornal Correio da Manhã foi publicado o relatório do delegado auxiliar Nascimento Silva sobre o papel desempenhado pelo oficial infiltrado: "O $2^{\circ}$ tenente do Exército, Jorge Elias Ajus, fingia-se conspirador e se intrometera nas reuniões sediciosas com o fim preestabelecido de fazer chegar ao conhecimento do chefe de polícia quanto sucedia. (...)"32

Em I8 de novembro os operários das fábricas de tecidos do Rio de Janeiro, Niterói, Petrópolis e Magé cruzaram os braços às I6 horas. Era o estopim para a eclosão do movimento revolucionário. Trabalhadores metalúrgicos e da União dos Operários em Construção Civil também aderiram ao movimento grevista. Em pouco tempo os operários convergiram em peso para o Campo de São Cristóvão. Por volta das I7 horas o local já estava tomado de trabalhadores. Autoridades tentavam controlar a situação. Assim registrou o Jornal do Brasil:

Ontem, cerca das 17 horas, foram chegando ao Campo de São Cristóvão grupos de operários, que em atitude pacífica, iam cada vez mais engrossando a onda. A Polícia do $19^{\circ}$ Distrito que tivera conhecimento antecipadamente desta reunião estava a postos (...)..$^{33}$

O local escolhido para a concentração operária foi o Campo de São Cristóvão por causa de sua proximidade com a Intendência de Guerra. Após ser conquistada pela massa operária, forneceria armamentos e fardamento para os insurretos. Fardados os operários esperavam angariar apoio de muitos soldados. Unidos iriam para a cidade onde a prefeitura seria dinamitada, depois atacariam o Palácio da Polícia e depois o Quartel General da Brigada Policial. Enquanto isso outro grupo de operários da Gávea e Jardim Botânico atacariam o Palácio do Catete e logo depois a Câmara onde prenderiam os deputados. As torres da Light seriam dinamitadas para deixar a cidade sem luz. (ADDOR, I986, p. I62 e I63).

A polícia recebeu autorização para dissolver a massa operária que se concentrava no Campo de São Cristóvão. Policiais tentaram prender os operários que ali estavam reunidos, fato que enfureceu ainda mais os insurretos. Houve enfrentamentos entre operários e

${ }^{32}$ Correio da Manhã (29/12/I9I8).

33 Jornal do Brasil (19/II/I9I8). 


\section{C) HitcastórRICA}

policiais. Quando a repressão utilizou armas de fogo para reprimir a multidão, os operários mostraram que estavam preparados para o embate. Se defenderam explodindo bombas de dinamite e atirando com armas de fogo. Os tiros foram trocados de ambos os lados. $\mathrm{O} \mathrm{IO}^{\circ}$ Distrito Policial foi invadido pelos operários que o destruíram em fúria. O general Almada, chefe da Intendência de Guerra, mandou atirar contra os amotinados que tentassem a invasão para tomar as armas do Exército. A cavalaria do exército libertou a delegacia policial e muitos operários fugiram pelos fundos, adentrando em casas adjuntas à delegacia. As torres da Light foram dinamitadas. Do morro de Santa Tereza os operários arremessavam petardos contra o quartel da Polícia Militar na Evaristo da Veiga. A Brigada Policial chegou para auxiliar o Exército e os operários a receberam com uma bomba. A delegacia já estava nas mãos da Polícia e do Exército. Muitos operários fugiram de forma desorganizada. Um grande número se dirigiu para a Rua Figueira de Mello, mas os soldados do Exército dispersaram os operários que estavam em fuga. Foi preso José Oiticica como chefe do movimento revolucionário. (BANDEIRA, 2004, p. I80).

$\mathrm{O} 55^{\circ}$ Batalhão de Caçadores ocupou estrategicamente as esquinas das principais ruas da região. No cruzamento das principais ruas havia uma força de 25 praças comandada por um tenente. Bondes ficaram proibidos de circular nas ruas ocupadas. Botequins da região foram fechados para impedir aglomerações. Automóveis foram revistados. O Palácio do Catete reforçou sua segurança, que já contava com um pelotão do $9^{\circ}$ de Caçadores, e recebeu uma companhia de guerra do $56^{\circ}$ Caçadores. O chefe de polícia Aurelino Leal foi elogiado pela burguesia por sua atitude enérgica contra os revoltosos. Tropas da Vila Militar ocuparam o centro têxtil de Bangu. A Marinha ocupou a Zona Portuária e as fábricas passaram a ser vigiadas pela Polícia Militar. Sedes de associações operárias foram invadidas e lacradas. Casas de militantes operários ou de suspeitos foram invadidas. Foram presos mais de cem operários com a possibilidade de serem enviados para a Ilha de Fernando de Noronha. A Marinha estava de sobreaviso com rebocadores vigiando a Baía de Guanabara com receio de algum atentado anarquista pelo mar. Os jornais da grande imprensa continuavam sua campanha xenófoba de associar o movimento operário com agitadores estrangeiros. Associavam os militantes anarquistas com agentes estrangeiros que supostamente haviam participado do levante. Assim publicou o Jornal do Brasil:

A polícia, devido aos últimos acontecimentos que alarmaram o país, colheu nas suas malhas quase Ioo anarquistas, insistentes estimuladores dos 


\section{C) HițTon T́RICA}

desagradáveis movimentos por parte do nosso operariado. Entre esses homens, a mantenedora da ordem pública apenas encontrou um brasileiro, o que basta para deixar fora de dúvida que o anarquismo não encontra terreno propício no espírito dos trabalhadores nacionais". ${ }^{34}$

Essa notícia foi vinculada com objetivo de confundir a população brasileira e criminalizar o movimento operário como fruto de desajustados estrangeiros sem qualquer ligação com a cultura nacional. Contudo, os líderes do movimento foram José Oiticica, Astrojildo Pereira, João da Costa Pimenta e Agripino José, todos brasileiros. Estudantes do Colégio Pedro II e da Escola de Medicina exigiram a liberdade do professor José Oiticica. Mesmo com toda repressão violenta do governo e com o fracasso do levante anarquista, metalúrgicos, tecelões e parte dos trabalhadores da construção civil continuaram de braços cruzados. Eram 20630 tecelões em greve. A UOFT orientava os grevistas a manterem a greve até conseguirem liberdade de pensamento, seis dias de trabalho por semana, salário mínimo e 8 horas de trabalho por dia. No dia 22 de novembro, Delfim Moreira, presidente interino, assinou o decreto $\mathrm{n}^{\circ}$ I3.295 que fechou a União Geral dos Trabalhadores, a União dos Operários em Fábricas de Tecidos, a União dos Operários Metalúrgicos e a União dos Operários em Construção Civil. As autoridades alegaram que a UGT induziu os operários ao ataque a Intendência de Guerra com o objetivo de estabelecer no Brasil o temido regime dos sovietes russos. É notória a ignorância das elites brasileiras a respeito do que acontecia na Rússia, principalmente das autoridades policiais. (BANDEIRA, 2004, p. I8I-I87).

Os trabalhadores em massa se organizaram e se mobilizaram para lutar pela absolvição dos militantes presos, acusados de serem os líderes da malograda insurreição. A pressão operária alcançou o objetivo almejado, pois seis meses depois foram liberados a tempo de participarem das manifestações do $I^{\circ}$ de Maio do ano seguinte. (PEREIRA, 2OI2, p. 54).

O legado da Revolução Bolchevique, a recente greve da Cantareira, as notícias da revolução na Alemanha, a mobilização operária no rastro da greve geral de 1917 e as adesões de alguns militares de baixa patente em protestos populares moviam os operários em seu objetivo de concretizar a anarquia em uma realidade social. Porém os militares não aderiram ao movimento insurgente. Na verdade, cumpriram fielmente seu papel de força repressora

34 Jornal do Brasil (28/II/I918). 


\section{C) Hitcastórica}

do Estado burguês. Os revolucionários tentavam trazer os militares para o lado operário com distribuição de boletins exortando-os a ficarem do lado do povo. Pois na Rússia os militares haviam se unido ao proletariado e esse seria um dos caminhos para a derrubada do capitalismo no Brasil. Porém muitos militantes operários foram presos antes de aproximar os militares do proletariado. Também foi um militar, José Elias Ajus, que se infiltrou no movimento para espioná-lo e controlá-lo. Os militantes operários pretendiam transformar a greve em uma greve geral, que se transformaria em uma revolução social. Tinham por objetivo concretizar a derrubada do poder constituído como havia acontecido na Rússia. Seriam criados conselhos de operários e soldados para pavimentar a construção de uma nova sociedade sem classes sociais, sem o Estado burguês que o massacrava em sua luta por melhores condições de vida. (ADDOR, 1986, p. I66 e I67).

Em janeiro de 1919 foi promulgada a primeira lei de compensação para os trabalhadores. Alguns patrões anunciaram que concederiam a jornada de trabalho de 8 horas. Curiosamente muitas empresas, entre elas o Jornal do Comércio, deram folga para seus empregados no dia $I^{\circ}$ de maio. Porém eram concessões isoladas, que dependiam da boa vontade do patrão. Essas pequenas concessões tinham o objetivo de acalmar os trabalhadores e afastá-los da combativa militância anarquista. Porém o sindicalismo revolucionário demonstrava força e combatividade proletária.

\section{Conclusão}

A insurreição anarquista de 1918 tem sido pouco abordada pelos historiadores que estudam o movimento operário no referido período. Poucos historiadores deram a devida atenção a esse episódio. A violenta repressão e as medidas tomadas para impedir outra insurreição dessa natureza demonstram a relevância desse fato histórico. As elites ficaram alarmadas com a grande mobilização operária e a elaboração de uma organizada estratégia para a tomada de poder no Distrito Federal. Essa tentativa revolucionária evidenciou que a conquista da Capital da República era possível. O anarquismo era a principal ideologia de combate proletário contra a exploração capitalista. Proporcionava meios eficientes dos operários interpretarem e entenderem a realidade material a qual estavam submetidos. Após a conquista de poder pelos marxistas russos, o combativo sindicalismo revolucionário no Brasil se tornou ainda mais combativo. Entendemos que a insurreição anarquista de 1918 representou essas novas perspectivas de luta dos sindicatos revolucionários. A Rússia 


\section{C) HitșTórICA}

Soviética havia legado o caminho para a derrubada do capitalismo e abriu novas perspectivas para o movimento operário.

Um importante desdobramento da insurreição anarquista foi a criação de um partido comunista em I9I9, no Rio de Janeiro. Era na verdade uma nova organização anarquista, cujo termo "comunista" era apenas o nome da organização. Não existia nenhum livro de Marx, traduzido para o português, publicado no Brasil. (SANTOS, 20I8, p. 200). Assim foi a criada uma organização anarquista intitulada "Partido Comunista do Brasil". O nome representou a força, influência e esperança que a revolução bolchevique provocou nos anarquistas brasileiros. Influenciados pela Revolução Russa, Astrojildo Pereira e José Oiticica, com outros 20 militantes anarquistas fundaram um primeiro partido comunista.

Tratava-se, na realidade, de uma organização tipicamente anarquista, e a sua denominação de 'Partido Comunista' era um puro reflexo, nos meios operários brasileiros, da poderosa influência exercida pela revolução proletária triunfante na Rússia, que se sabia dirigida pelos comunistas daquele país. O que não se sabia ao certo é que os comunistas que se achavam à frente da Revolução Russa eram marxistas e não anarquistas. (...)" (PEREIRA, 20I2, p. 72).

Segundo Astrojildo Pereira, reuniões foram realizadas entre os militantes mais ativos e combativos do movimento operário para elaborar medidas que fizessem funcionar a organização anarquista como um grupo bem organizado. Ao invés de estatutos foram criadas "bases de acordos". O objetivo desse "partido comunista" era "promover a propaganda do Comunismo Libertário, assim como organização de núcleos comunistas em todo o país". (PEREIRA, 20I2, p. 7I).

Em abril de 1919 os organizadores do partido convocaram representantes de outros grupos anarquistas, que se intitulavam comunistas, para participarem da Conferência Comunista que ocorreria em fins de junho no Distrito Federal. Foi realizada entre os dias 2I e 23 de junho e compareceram 22 delegados dos estados do Rio de Janeiro, Alagoas, Pernambuco, Minas Gerais, Paraíba, São Paulo e Rio Grande do Sul. Entre os delegados eram 17 brasileiros natos, três mulheres e o restante eram estrangeiros que viviam há muito tempo no Brasil. Essa conferência também foi considerada como congresso de fundação da organização libertária. Segundo Edgard Leuenroth foi uma "assembleia de todo o 


\section{C) HitistóñICA}

movimento anarquista do Brasil". A primeira reunião ocorreu no Centro Cosmopolita e foi acompanhada por centenas de operários. Foi aprovado um programa do partido, redigido por José Oiticica, intitulado Princípios e fins do comunismo. Um longo documento, muito bem organizado, dividido em itens em que a organização defendia a necessidade da extinção do Estado, de toda autoridade religiosa, da propriedade privada e das leis. Os meios de produção, como as fábricas, pertenceriam aos operários. As necessidades gerais é que ditariam o tempo de trabalho. A produção seria armazenada e distribuída a cada indivíduo de acordo com suas necessidades. As decisões políticas seriam decididas em assembleias públicas. Com base nesse documento, José Oiticica publicou seu Catecismo Anarquista.

Em agosto foi publicado um novo jornal anarquista, Spartacus, por José Oiticica e Astrojildo Pereira. Era o veículo de informações do núcleo carioca desse partido comunista de 1919. Seu início não foi fácil, por causa da constante repressão policial. Assim registrou o periódico Spártacus:

Na impossibilidade momentânea de publicar Spártacus diariamente, como já fora anunciado, resolvemos, de acordo com o camarada Oiticica, constituir-nos em Grupo Editor de Spártacus semanário, até que ele possa tornar-se cotidiano. Não pouparemos esforços para que isso se realize o mais cedo possível. As dificuldades nos estimulam. Falhou a primeira tentativa, mercê da tratangem burguesa, falhou a segunda pelos mesmos motivos. Faremos terceira, quarta, quinta tentativas, por outros meios, com outra gente. E Spártacus, vespertino e diário, sairá... ${ }^{35}$

Foram publicadas 24 edições até janeiro de 1920 , alcançando grande circulação entre os trabalhadores. O quarto número, publicado em 23 de agosto de I9I9, anunciou que as tiragens do periódico estavam crescendo gradativamente.

4.000, 6.000 e 8.00o exemplares. Aqui estamos no $4^{\circ}$ n. de Spártacus, com uma promissora tiragem de 8.000 exemplares. Isso prova que Spártacus,

35 Spártacus (02/08/1919). 


\section{C) HitistóñICA}

embora modestamente, sabe exprimir o etos de revolta e os anseios de esperança das massas proletárias. (.... $)^{36}$

Depois do surgimento do periódico Spártacus houve uma grande greve dos trabalhadores gráficos seguida de forte repressão governamental. Os periódicos anarquistas foram os principais alvos das forças de repressão estatal. Em setembro a polícia retirou os exemplares de A Plebe de estações ferroviárias e dos correios. O jornal Spártacus também foi apreendido. (DULLES, I977, p. 92-93). Após todas as turbulências de setembro de 1919, as autoridades se mobilizaram para reprimir a agitação operária. O Chefe de Polícia Geminiano da França se reuniu com o ministro da Justiça para discutir uma maneira de acabar com as greves e revoltas operárias que estavam ganhando força, principalmente na Capital Federal. Além da repressão aos jornais anarquistas, a polícia invadiu as sedes da União dos Sapateiros e da União dos Operários em Construção Civil. O cenário para as elites era preocupante pois mesmo com toda a repressão ao movimento insurrecional anarquista em fins de I9I8, as greves e manifestações operárias estavam crescendo novamente e inflamando a massa proletária. Em 1920 aconteceu o Terceiro Congresso Operário Brasileiro. Tais fatos demonstram a força do sindicalismo revolucionário e sua inspiração ideológica anarquista. O anarquismo continuava forte em fins da segunda década da Primeira República e era brutalmente combatido pelos detentores do poder. O fantasma da emancipação dos despossuídos, bestializados, indesejáveis tirava o sono da burguesia e das autoridades.

A insurreição anarquista de I9I8 não pode ser apagada por aqueles que se propõem a analisar a História do movimento operário brasileiro. Inúmeros seres humanos foram presos, afastados de suas famílias, torturados e exterminados para que a população conquistasse direitos trabalhistas básicos, os quais todos usufruímos atualmente. Cem anos se passaram e nossos direitos continuam sendo alvos de ataques constantes de governantes e empresários.

\section{Referências}

ADDOR, Carlos Augusto. A insurreição anarquista no Rio de Janeiro. Rio de Janeiro: Ed. Achiamé, 2002.

${ }^{36}$ Spártacus (23/08/1919). 


\section{G) GitșTórICA}

; Deminicis, Rafael (organizadores). História do anarquismo no Brasil (2 volume). Rio de Janeiro: Achiamé, 2009.

BANDEIRA, Moniz. O ano vermelho. Rio de Janeiro: Civilização Brasileira, 1967.

BATALHA, Cláudio H. M. O movimento operário na Primeira República. Rio de Janeiro: Jorge Zahar Ed., 200o.

BRANDÃO, Octávio. Combates e batalhas. Vol. ı: Memórias. São Paulo: Editora Alfa - Ômega, 1978.

CARONE, Edgard. Movimento operário no Brasil (I877-I944). São Paulo: Ed. DIFEL, 1982.

COLOMBO, Eduardo et alii. História do movimento operário revolucionário. São Paulo: Editora Imaginário, 2004.

DEMICINIS, Rafael Borges; REIS, Daniel Aarão (organizadores). História do anarquismo no Brasil. (I ${ }^{o}$ volume). Niterói: edUFF : Rio de Janeiro: MAUAD, 2006.

DIAS, Everardo. História das lutas sociais no Brasil. São Paulo: Editora Alfa-Omega, I977.

DULLES, John W. F. Anarquistas e comunistas no Brasil: 190o-I935. Rio de Janeiro: Nova Fronteira, 1973.

FAUSTO, Boris. Trabalho urbano e conflito social: 1890-I920. São Paulo: Companhia das Letras, 2016.

FEIJÓ, Martin Cezar. Formação política de Astrojildo Pereira. Belo Horizonte: Ed. Oficina de livros, 1990.

FERREIRA, Maria Nazareth. A imprensa operária no Brasil, I88o-I920. Petrópolis: Editora Vozes, 1978.

FERRO, Marc. O Ocidente diante da revolução soviética. São Paulo: Ed. Brasiliense, I984.

HALL, Michael M.; PINHEIRO, Paulo Sérgio. A classe operária no Brasil I889-I93o. São Paulo: Editora Alfa Omega, 1979.

HARDMAN, Francisco Foot. Nem pátria, nem patrão! São Paulo: Ed. UNESP, 2002. ; LEONARDI, Victor. História da indústria e do trabalho no Brasil: das origens aos anos 20. Rio de Janeiro: Ed. Ática, I99I.

LAMOUNIER, Aden Assunção. José Oiticica: itinerários de um militante anarquista. Curitiba: Editora Prismas, 2016.

LINHARES, Hermínio. Contribuição à história das lutas operárias no Brasil. São Paulo: Ed. AlfaOmega, 1977 .

MARAM, Sheldon Leslie. Anarquistas, imigrantes e o movimento operário brasileiro (I890-I920). Rio de Janeiro: Ed. Paz e Terra, 1979. 


\section{C) HitcastórRICA}

OITICICA, José. A doutrina anarquista ao alcance de todos. São Paulo: Editora Econômica, 1983.

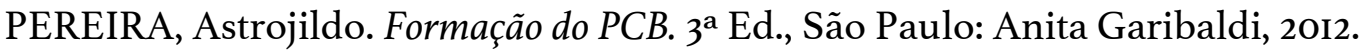

PLANCHEREL, Alice Anabuki. Memória e omissão: anarquismo e Octávio Brandão. Maceió: EDUFAL, 1997.

RAMOS, Renato; SAMIS, Alexandre. Domingos Passos: o Bakunin brasileiro. São Paulo: Faísca Publicações Libertárias, 2009.

REIS, Daniel Aarão. História do marxismo no Brasil. Rio de Janeiro: Ed. Paz e Terra, I99I. RODRIGUES, Edgar. Socialismo e sindicalismo no Brasil. Rio de Janeiro: Ed. Laemmert, I969. . ABC do sindicalismo revolucionário. Rio de Janeiro: Ed. Achiamé, 1987. . Alvorada operária. Rio de Janeiro: Ed. Mundo Livre, 1979. . Novos rumos. Rio de Janeiro: Ed. Mundo Livre, 1979.

ROMANI, Carlo. Oreste Ristori: uma aventura anarquista. São Paulo: Annablume, 2002. SALLES, Iza. Um cadáver ao sol. Rio de Janeiro: Ediouro, 2005.

SAMIS, Alexandre. Clevelândia: anarquismo, sindicalismo e repressão política no Brasil. Ed. Imaginário, 2002. - Minha pátria é o mundo inteiro: Neno Vasco, o anarquismo e o sindicalismo revolucionário em dois mundos. Lisboa: Letra Livre, 2009.

SANTOS, Hamilton Moraes Theodoro dos. Anarquismo e a formação do Partido Comunista do Brasil ( $3^{a}$ ed.). Rio de Janeiro: Rizoma Editorial, 2018.

SODRÉ, Nelson Werneck. A História da imprensa no Brasil. Rio de Janeiro: Editora Civilização Brasileira, 1966.

TOLEDO, Edilene. Anarquismo e sindicalismo revolucionário: trabalhadores e militantes em São Paulo na Primeira República. São Paulo: Ed. Perseu Abramo, 2004.

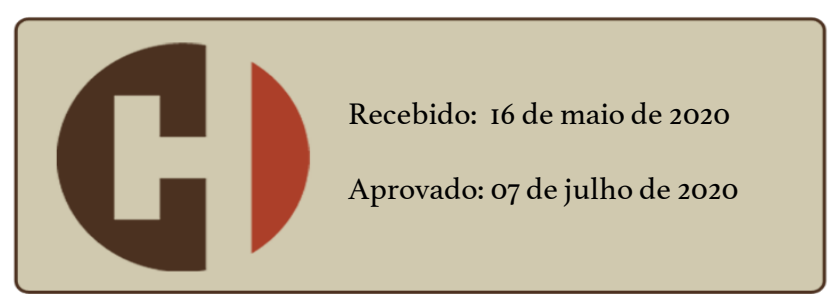

